\title{
How Do Cultural and Institutional Distance Affect China's OFDI towards the OBOR Countries? ${ }^{1}$
}

\author{
Lin Zhang \\ Shanghai University of International \\ Business and Economics, \\ Boshi Building Room 303, \\ 1900 Wen Xiang Road, Songjiang, \\ Shanghai 201620, PR China \\ E-mail: zhanglin@suibe.edu.cn \\ Zheqian Xu \\ Shanghai University of International \\ Business and Economics, \\ Boshi Building Room 303, \\ 1900 Wen Xiang Road, Songjiang, \\ Shanghai 201620, PR China \\ E-mail: 553018593@qq.com
}

\begin{abstract}
In order to examine the impact of cultural and institutional distance on China's OFDI towards the One Belt, One Road (OBOR) area, the paper selects 28 countries along The Belt and Road. The empirical results using panel data from 2006-2014 indicate that institutional distance is negatively correlated with China's outward foreign direct investment (OFDI). At the same time, cultural distance interacts with bilateral trade, resulting in a "benefit of foreignness" effect.
\end{abstract}

Keywords: cultural distance, institutional distance, OBOR, OFDI

1 This paper is sponsored by the Central and Eastern European Countries Research Center at the Shanghai University of International Business and Economics. 


\section{Introduction}

The Silk Road Economic Belt and the 21st-Century Maritime Silk Road are the initiatives first introduced by China's President Xi in 2013 during his visits to Kazakhstan and Indonesia, respectively. Now they are known as The Belt and Road or One Belt, One Road (OBOR). OBOR includes 65 countries which jointly account for $62.3 \%, 30.0 \%$ and $24.0 \%$ of the world's population, GDP and household consumption, respectively (Chin \& He, 2016, p. 4). The Belt and Road initiative aims to promote the connectivity of Asian, European and African continents and their adjacent seas, establish and strengthen partnerships among the countries along the route (NDRC, 2015).

At present, the world economy is recovering slowly and global development is uneven. Also, the international trade and investment rules for multilateral trade and investment are undergoing major adjustments. It is the key stage of economic transformation for Asian and European countries. Therefore the developmental vitality and cooperation might play a significant role in that area. The OBOR initiative is exactly the common demand for those countries, and it also provides new opportunities for cross-country cooperation and growth through opening up to other countries. Chinese enterprises have made direct investments to 50 countries along OBOR and the amount reached 18.93 billion dollars in 2015. The investment flow increased 38.6\% year-on-year, which is twice the growth rate towards the world. By the end of 2015, the stock of Chinese direct investment in the OBOR countries reached 115.68 billion dollars, accounting for $10.5 \%$ of total Chinese direct investments stock (Ministry of Commerce of PRC, 2016, p. 92). Thus, we could conclude that those OBOR countries will become the new growth source for China's outward foreign direct investment (OFDI).

Currently we can already see some achievements in the cooperation of energy equipment and infrastructure between China and those countries. Due to great differences in the scale of economy, industrial structure and trade volume, Chinese investments have mostly been injected in Southeast Asian countries or Russia, having resulted in serious imbalance of investments in the OBOR region. Besides, there are quite complicated security concerns such as different powers, religions, cultural conflicts embedded in that region, which would further increase the risks of future cooperation in investments. Against such background the study of cultural and institutional distance on China's OFDI will have great significance for bilateral investments between China and these countries and further extend the cooperation to realize risk sharing and win-win 
situation for all related countries. Cultural distance is defined as the difference between the national culture of the home country (China) and those of the host economies (Yuanfei \& Fuming, 2012, p. 49). It measures the extent to which normative forces influence FDI activities. Institutional distance is the extent of similarity or dissimilarity between home and host countries' institutions (Kostova, 1997). Therefore, we refer to institutional distance as an absolute distance between institutions in destination and China.

The remainder of the article is arranged as follows. Section 2 describes literature related to our research and our possible contribution to the literature. Section 3 introduces the situation and characteristics of China's investments in the OBOR countries. Section 4 investigates the effects of cultural and institutional distance on China's OFDI by constructing a gravity model and discusses empirical results, and Section 5 concludes the article.

\section{Review of literature}

This paper is motivated by a broad literature on the location choice of investment by multinational enterprises. Scholars mainly research developed countries to analyse the motivations of their enterprises in investment activities; Dunning's eclectic paradigm suggests three primary motivations behind international investments of firms from developed countries as market-, efficiency- (or cost reduction) or resource- (or strategic asset) seeking. Apart from the above motivations, they have started to pay attention to the cultural or institutional factor of the host country on attracting foreign investments.

\subsection{Cultural distance and FDI}

Studies have showed mixed results in terms of the relationship between cultural distance and OFDI till now. FDI is particularly sensitive to 'soft' barriers, such as the quality of governance systems and cultural differences, firms substitute FDI by trade when cultural differences between the parent and the home country increase (Lankhuizen et al., 2011). Xu and Li (2011) indicated that cultural distance is negatively correlated with China's OFDI, that is to say, the greater cultural difference between China and the host country, the less direct investment from China to the host country Flores and Aguilera (2007) arrived at the same conclusion in their research on how US multinational corporations made location decisions referring to overseas direct investment. In contrast, 
some empirical researches suggest that firms from dissimilar cultures are more prone to undertake FDI into emerging markets than more similar ones (Thomas \& Grosse, 2001; Randy \& Dibrell, 2002). While at the early stage of FDI, cultural distance is negatively associated with its choice of location, the influence of cultural distance may become weaker in the later stage. Yin and $\mathrm{Lu}$ (2011) suggested that it is not simply negative or positive correlation of cultural distance on the location choice of foreign investment, and it is not linearly displayed, and by integrating the effects of "liability of foreignness" and "benefit of foreignness", the result indicates an S-shape relationship between cultural distance and FDI flows.

\subsection{Institutional distance and FDI}

Institutional distance has recently been identified as a major factor that affects multinational enterprises' (MNEs) entry mode choices since the countries' differences are perceived "as a barrier to obtaining local knowledge, making it difficult for the MNE to manage its foreign subsidiaries on its own" (Xu \& Shenkar, 2002, p. 613). In addition, it has an asymmetric effect on FDI depending on whether investors choose countries with better or worse institutions. In the latter case, large institutional distance discourages FDI inflows, but this deterring effect is diminished for destination countries with substantial resources (Aleksynska \& Havrylchyk, 2013). Using the distinction between formal and informal institutions, Dikova and others (2010) have found that firms undertaking M\&A deals in institutionally more distant countries are more likely to withdraw the deal. Since politically distant target countries could increase the complexity of the deal. Chinese OFDI tends to be less risk averse, Buckley and others (2007) found that most Chinese OFDI was government led and promoted by political affiliations and connections between China and other developing host country governments. Therefore, they suggested that China's OFDI is attracted to natural resources in high (political) risk countries. While other studies tend to show limited evidence linking Chinese OFDI and an uncertain political/institutional environment (Cheung \& Qian, 2009; Kolstad \& Wiig, 2012), Ramasamy and others (2012) indicated that the driving force for China's OFDI may be different in terms of the ownership. State-controlled firms are attracted to countries with large natural resources and risky political environments and private firms are more market seekers.

Furthermore, by protecting property from political and other risks, bilateral investment treaties (BITs) could substitute for weak domestic institutions and 
promote FDI flows to developing countries (Neumayer \& Spess, 2005; Busse et al., 2010). However, the effect of a BIT crucially depends on the quality of political relations between the signatory countries; it increases FDI more between countries with tense relationships than between friendly countries (Desbordes \& Vicard, 2009). Also BITs are more effective in promoting firms to locate in signatory countries with a worse institutional environment (Zong et al., 2012). Li and others (2014) show that the institutional distance suppresses China's OFDI. However, BITs not only reduce barriers for China's enterprises to go out, but also have a significant reverse regulation on the suppression of institution distance.

For the empirical exercise, we focus on the impact of both these two aspects: how culture and institutions affect Chinese firms' location choice of investment along the Belt and Road region. Our paper contributes to a growing literature that analyses the determinants of Chinese outward foreign direct investment by selecting 28 OBOR countries between 2006 and 2014.

\section{Characteristics of China's OFDI towards the OBOR countries}

With its economy entering the state of "new normal", China is witnessing a dramatic change from a capital importing country to a capital exporting country. Outward investment from China rose by about 4\% to 128 billion dollars (UNCTAD, 2016, p. 48). As a result, China remained the third largest investing country worldwide, following the United States and Japan. According to the data from the Ministry of Commerce, Chinese non-financial investment in 2015 amounted to 118.02 billion dollars, a growth of $14.7 \%$ year-on-year, and continuing growth in outbound investments over the past 13 years (Xinhua, 2016). In recent years, private enterprises have become the main driving forces with investment diversity and upgrade of their position within global value chains. Technology-seeking OFDI from China in recent years is likely to intensify and necessitate upgrading of the industrial structure, while Chinese investments will also contribute to the development of host economies, especially in developing countries that share some basic features with China and have investment needs that the country is well-suited to match (OECD, 2015, p. 21). That explains the rapid increases of Chinese investment flow to the OBOR regions to some extent. 


\subsection{The size of investments extends further}

Chinese investments in the Belt and Road region are extremely unbalanced and have three levels in general. By the end of 2014, investment stock flows in Southeast Asia reached 47.63 billion dollars (see Fig. 1), average growth rate up to $51 \%$ during the period between 2006 and 2014, and the area ranked first in attracting investments among those OBOR countries.

Figure 1. China's outward FDI stock in the OBOR initiative area (100 million US dollars)

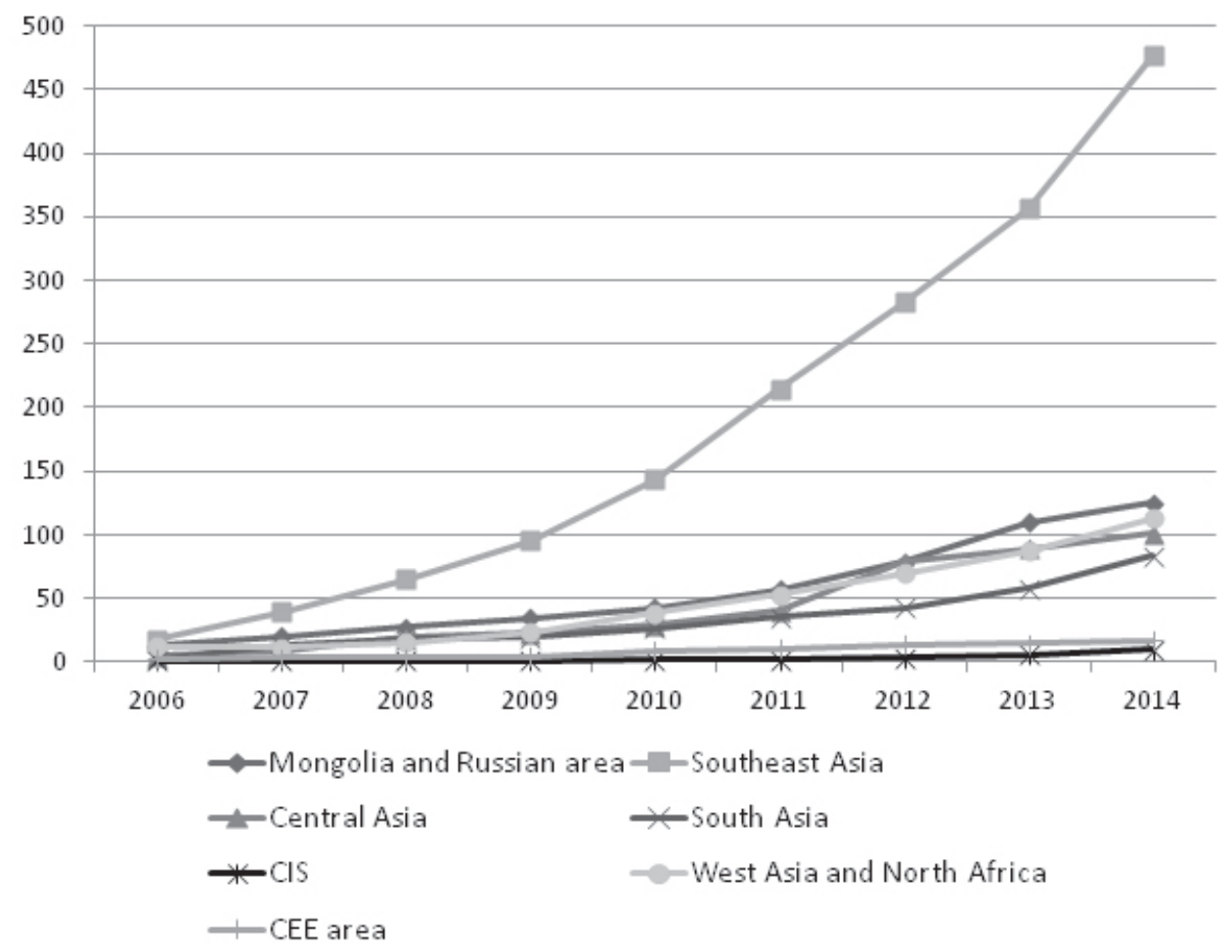

Source: Statistical Bulletin, 2015

It was followed by Mongolia and Russia (12.46 billion dollars), West Asia and North Africa (11.304 billion dollars), Middle Asia (10.094 billion dollars), CIS (9.332 billion dollars) and South Asia ( 8.227 billion dollars), and 
the $16 \mathrm{CEE}$ countries ${ }^{2}$ came last, attracting only 1.7 billion dollars of Chinese investments, less than $4 \%$ that of in Southeast Asia. ${ }^{3}$

Among these regions, Middle Asia has relatively faster growth rate in attracting investment from China, reaching 26.9\% year-on-year from 2006 to $2014 .{ }^{4}$ This is partly due to sufficient oil resources in that area, especially in Kazakhstan. As to the CEE countries, although the FDI stock is the lowest, it grew approximately fortyfold in 2014, compared with 2003. And we could expect it will grow even faster in the future as both parties explore new space for cooperation in green economy, i.e. green agriculture, ecological environment protection and clean energy under the improved $16+1$ cooperation mechanism. In addition, Southeast Asia has the most investments from China in the background of OBOR. This is not only due to the free trade zone agreement signed between China and ASEAN but also because they are culturally and geographically closer.

\subsection{More firms invest in the area}

According to Figure 2, the investments of Chinese enterprises mainly went to ASEAN. Until the end of 2015, there were 48.4\% Chinese firms who chose Southeast Asia as a host country for investment. Next to Southeast Asia, the Mongolia and Russian area attracted around $17.1 \%$ of firms. ${ }^{5}$ It is almost in the same trend compared with the scale of investments attracted. Although Chinese enterprises increased investments in CEE countries since the establishment of the $16+1$ cooperation framework in 2012, only $1.6 \%$ enterprises joined in. For individual countries, Russia, Singapore and Vietnam are top three in terms of attracting Chinese firms' investment, accounting for $11.4 \%, 8.9 \%$ and $8.4 \%$

2 Mongolia and Russian area refers to Russia and Mongolia; Southeast Asia includes Singapore, Malaysia, Indonesia, Myanmar, Thailand, Cambodia, Vietnam, Brunei, the Philippines, East Timor, Laos; West Asia and North Africa include Iran, Iraq, Turkey, Syria, Jordan, Lebanon, Israel, Palestine, Saudi Arabia, Yemen, Oman, the United Arab Emirates, Qatar, Kuwait, Egypt, Bahrain; South Asia includes India, Pakistan, Bangladesh, Sri Lanka, Afghanistan, Nepal, Maldives, Bhutan; the Commonwealth of Independent States includes Ukraine, Georgia, Azerbaijan, Armenia, Moldova, Belarus; Central Asia includes Kazakhstan, Uzbekistan, Turkmenistan, Kyrgyzstan, Tajikistan; the Central Eastern European countries include Poland, Romania, Czech Republic, Slovakia, Bulgaria, Hungary, Latvia, Lithuania, Slovenia, Estonia, Croatia, Albania, Serbia, Macedonia, Montenegro, Bosnia and Herzegovina.

3 Author's own calculation based on data from Statistical Bulletin, 2015.

4 Author's own calculation based on data from Statistical Bulletin, 2015.

5 Author's own calculation based on data from the Chinese website Zhiqiye, n.d. 
Figure 2. Investment track from China to the OBOR countries (no. of investments)

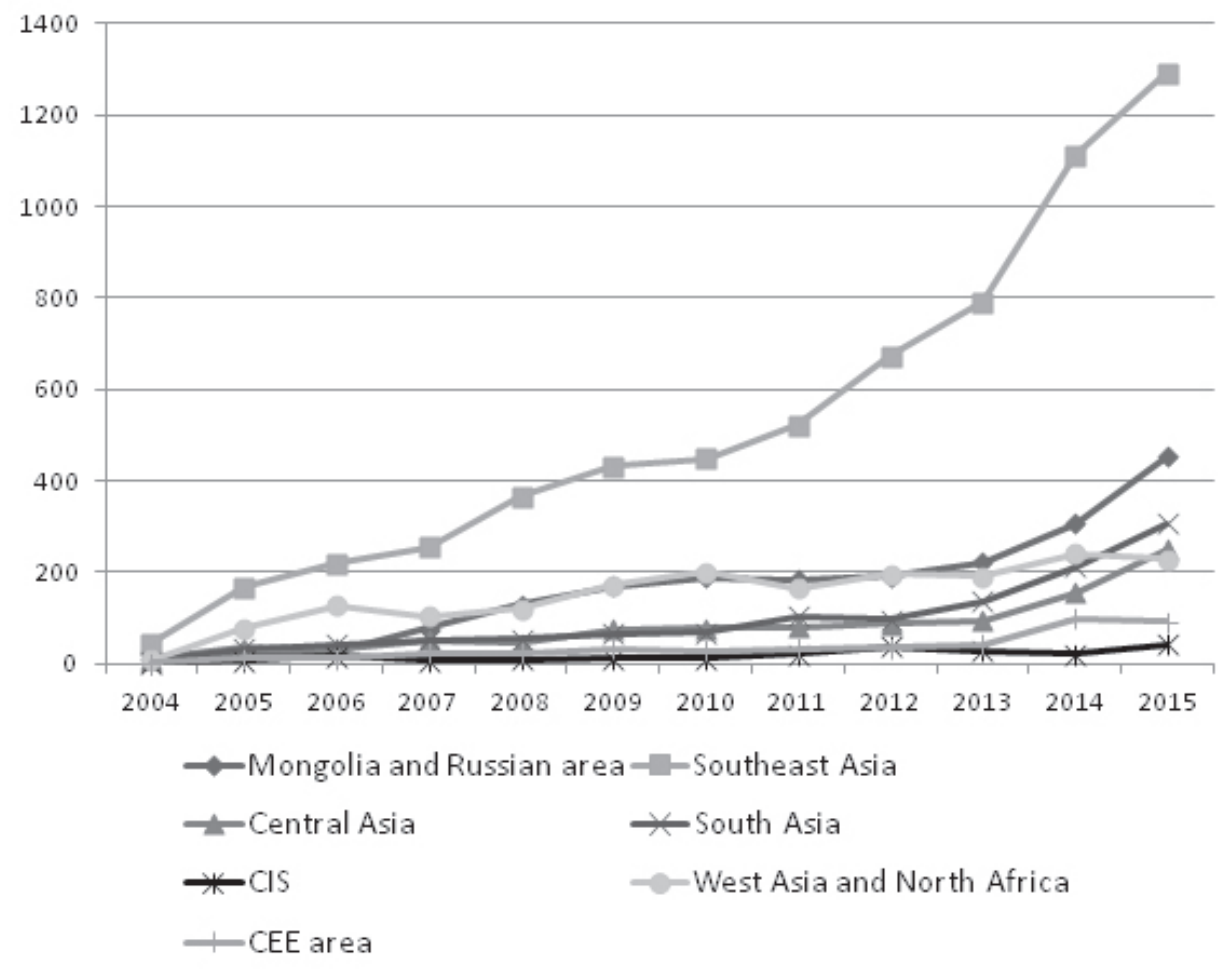

Source: Author's own calculation based on data in Zhiqiye (n.d.)

respectively (NDRC, 2015). Therefore, although Chinese firms have invested in more countries in recent years, cultural, institutional and geographical distance are still the main factors affecting the choice of location for investment abroad, and they are more inclined to invest in countries with cultural and geographical proximity. 


\subsection{Investments scattered in different industries}

In 2014, China's outward FDI flows to ASEAN reached 7.81 billion dollars, increasing $7.5 \%$ year over year and accounting for $51.5 \%$ of its outward FDI stock in the OBOR region. By the end of 2014, China had established more than 3,300 FDI enterprises which created 159,500 jobs for those countries (Statistical Bulletin, 2015, pp. 116-117). In terms of industrial structure of China's FDI stock in ASEAN in 2014, there were 7.23 billion dollar flow in the production and supply of electricity, heat, gas and water, accounting for $15.2 \%$ of the total (see Fig. 3), and the stock had been mainly distributed in Singapore, Myanmar, Cambodia, Indonesia and Laos. This is mainly due to the difficulty in providing electricity to households in some countries in the area, for example, only $56.1 \%$ of people had access to electricity in Cambodia in 2014 (World Bank, 2014). While Chinese enterprises have comparative advantage in supplying hydro and thermal electricity, for example, China Huadian Corporation have invested in a number of facilities which have been put into operation, including Indonesian Batam power plant, Indonesian Bali coal-fired power plant, Asahan Stage-I hydroelectric power station and Lower Stung Russei Chrum - the largest hydropower project in Cambodia (China Huadin Corporation, n.d.).

The second was leasing and business services, which received 6.84 billion dollars from China, accounting for $14.4 \%$ of the total, followed by manufacturing ( 6.13 billion dollars), mining ( 6.05 billion dollars), wholesale and retail trade (5.9 billion dollars) and finance ( 5.88 billion dollars). Leasing services, retailing and finance investments were mainly distributed in Singapore, manufacturing in Vietnam and Thailand, and natural resources in Indonesia and Laos, etc. Under the China-Singapore Free Trade Agreement, China and Singapore enhanced cooperation in financial services: in 2013, for example, the People's Bank of China (PBC) appointed the ICBC Singapore branch as the Renminbi (RMB) clearing bank in Singapore. Together with its transparent public institutions and highly efficient public sector, it is not surprising that Singapore attracts most finance investments from China among ASEAN countries.

Chinese investments in Mongolia and Russian area have turned from the extraction of traditional nature resources to business and financial services. Until the end of 2014, China's OFDI stock in Russia had reached 8.695 billion dollars, accounting for $12.5 \%$ of its OFDI stock in Europe, among which leasing and business services and finance accounted for $11.3 \%$ and $8.8 \%$ respectively. Although the ratios of the above two were still lower than 
that of manufacturing, which was $31.6 \%$, in terms of the capital flows in 2014 , leasing and business services attracted up to $15.9 \%$ investment in total (Statistical Bulletin, 2015, p. 122). In CIS and CEE countries, apart from intensive investments in infrastructure, there were increasing capital flows to electronics, software, information and finance industry.

Figure 3. Industrial distribution of China's FDI stock in ASEAN, by the end of 2014

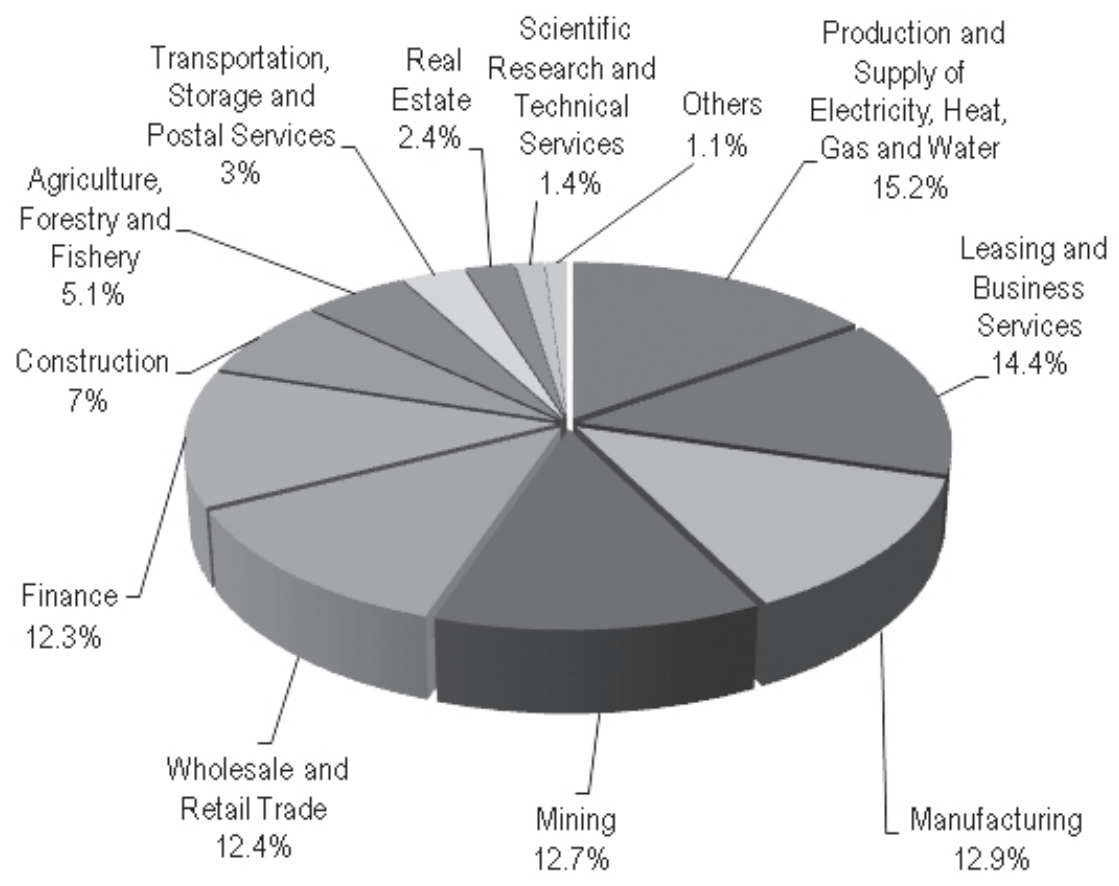

Source: Statistical Bulletin, 2015 


\section{Methodology and results}

\subsection{Variable measurement and data}

Given the availability of data, we selected the panel data of 28 host countries $^{6}$ along OBOR from 2006 to 2014, and our main focus was to investigate how cultural and institutional distance affects location choice of Chinese multinationals. In addition, considering the impact of transportation costs, trade and purchasing power, we included trade, GDP per capita and the interaction term of geographic distance and bilateral trade as control variables. Each variable is explained as follows:

The dependent variable is FDI stock from Chinese firms in each host countries. We chose FDI stock instead of FDI flows to these economies, as the stock variable is a more accurate measure of FDI location distribution (Filippaios, Papanastassiou \& Pearce, 2003; Yuanfei \& Fuming, 2012). Data for the dependent variable were obtained from official Chinese sources (MOFCOM), namely Statistical Bulletin of China's Outward Foreign Direct Investment.

Cultural Distance $(C D)$. It is defined as the difference between the national culture of China and these of the 28 host economies. It is measured by means of Hofstede's (1983) four cultural dimensions of power distance, uncertainty avoidance, individualism/collectivism and masculinity/femininity. Following the method developed by Kogut and Singh (1988), cultural distance was measured by the squared deviation along each of the dimensions of each country from China's score. Then the deviations are corrected for differences in the variances for each factor. The index is as below:

$$
C D_{i j}=\frac{1}{4} \sum_{k=1}^{4}\left(\left(\mathrm{I}_{k i}-\mathrm{I}_{k j}\right)^{2} / \mathrm{V}_{k}\right)
$$

where $\mathrm{I}_{k i}$ or $\mathrm{I}_{k j}$ represents the score for the $k^{\text {th }}$ cultural dimension of country $i(j) . \mathrm{V}_{k}$ represents the variance of the score for the $k^{\text {th }}$ dimension. $C D_{i j}$ stands for cultural distance of the $i^{\text {th }}$ country with respect to country $j$. Thus, a high score on the measurement means more cultural distance between China and country $i$. Hofstede's scale are collected from the World Values Survey (WVS) website.

6 It includes Russia, Singapore, Malaysia, Thailand, Philippines, Iraq, Turkey, Jordan, Lebanon, Yemen, Qatar, Kuwait, Egypt, Bahrain, India, Pakistan, Ukraine, Georgia, Azerbaijan, Armenia, Belarus, Uzbekistan, Kyrgyzstan, Tajikistan, Poland, Romania, Slovenia and Estonia. 
A potential problem about this measurement lies in the fact that it assumes that each cultural dimension has the same effects on cultural distance for different country or regions. However, with globalization, cultural conflicts may be narrowed. To overcome this difficulty, we modify the index as below referring to Qi (2012) and Tian (2015):

$$
C D_{i j}=\sqrt{\sum_{k=1}^{5}\left(\left(\mathrm{I}_{k i}-\mathrm{I}_{k j}\right)^{2} / \mathrm{V}_{k}\right)}+\left(1 / Y_{i j t}\right)
$$

where $Y_{i j t}$ represents years of the establishment of diplomatic relations between country $i$ (i.e. China) and country $j$, since the longer the relationships, the smaller the cultural distance. Also, we choose Hofstede's five cultural dimension model to overcome the problem of its overreliance on the survey of IBM employees.

Institutional Distance (ID). It captures both regulative and normative aspects of institutional environments. It is based on the World Bank's Worldwide Governance Indicators (WGI), which cover six dimensions, namely, voice and accountability, political stability, government effectiveness, control of corruption, regulatory quality and rule of law. Here, the former four aspects indicate the normative distance between two countries while the latter two show the regulative difference. We measure the institutional distance between China and the OBOR countries using the following formula:

$$
I D_{i j t}=\sqrt{\sum_{k=1}^{6}\left(\left(\mathrm{I}_{k i t}-\mathrm{I}_{k j t}\right)^{2} / \mathrm{V}_{k t}\right)}
$$

where $\mathrm{I}_{k i t}\left(\mathrm{I}_{k j t}\right)$ represents the score for the $k^{\text {th }}$ dimension of country $i(j)$ in year $\mathrm{t}$, and $\mathrm{V}_{k t}$ refers to the variance of the score for the $k^{\text {th }}$ dimension of all countries.

Bilateral trade (TRADE). Both the export from China to a host country and import from a host country capture the intensity of trade relations. Also, it indicates the relations between trade and investment, whether it is complementary or substitution. The data comes from UN Comtrade database.

GDP per capita $(A G D P)$ indicates the purchasing power of the local population or host country's market size, and the data come from the World Bank's World Development Indicators.

The interaction term of geographical distance and bilateral trade $\left(\ln D I S_{i j t} * \ln \operatorname{TRADE}_{i j(t-1)}\right)$. Distance $(D I S)$ is the product of distance from the capital of China (Beijing) to the host country's capital and the average annual price of crude oil from OPEC during 2006-2014. The geographical distance data is drawn from CEPII weighted distance. The purpose of constructing the new 
distance variable is to capture the costs for transportation due to geographical distance. With this term, we are able to test how geographical distance affects firms' investment location choice in the OBOR region via trade. Considering that the substitution for investment may lag behind the trade, we introduce trade lagged by one year.

\subsection{Estimation strategy}

Following the discussion on variables above, we formulated the regression model as follows:

$$
\begin{aligned}
\ln O F D I_{i j t}= & \beta_{0}+\beta_{1} C D_{i j t}+\beta_{2} I D_{i j t}+\beta_{3} \ln \operatorname{TRADE}_{i j(t-1)} \\
& +\beta_{4} \ln A G D P_{j t}+\beta_{5} \ln D I S_{i j t} \cdot \operatorname{lnTRADE} i j(t-1) \\
& +\mu
\end{aligned}
$$

where $i$ represents China, $j$ refers to host county. Our dependent variable is the total amount of China's OFDI stock to host countries.

Our panel data includes time invariant geographical distance which captured by country fixed effect, which is why the distance variable did not show up in Table 2. In addition, a year fixed effect is controlled to isolate the time trend of FDI stock in case of the estimates are overbiased. Therefore, by controlling both year and country fixed effect, we are able to control the impact of country-specific characteristics and some unobservable time-related factors on FDI stock.

\section{Table 1. Descriptive statistics}

\begin{tabular}{|c|c|c|c|c|c|}
\hline Variables & Mean & S.D. & Min & Max & Samples \\
\hline $\ln O F D I_{i j t}$ & 18.2469 & 2.554229 & 12.50618 & 23.75049 & 252 \\
\hline$C_{i j t}$ & 4.784077 & 1.091072 & 2.785037 & 7.089988 & 252 \\
\hline$I D_{i j t}$ & 8.183551 & 8.146696 & 0.8327145 & 40.3962 & 252 \\
\hline $\ln D I S_{i j t}$ & 13.07314 & 0.3796044 & 11.98016 & 13.6907 & 252 \\
\hline $\ln T R A D E_{i j t-1}$ & 22.22871 & 1.739615 & 16.96739 & 25.38749 & 252 \\
\hline $\ln A G D P_{j t}$ & 8.711454 & 1.158096 & 6.636629 & 11.21787 & 252 \\
\hline
\end{tabular}


Table 1 provides descriptive statistics for the abovementioned variables. China's FDI stock in host country ranges from 0.27 million dollars (12.5 in logarithm form) for Bahrain in 2006 to 20.6 billion dollars (23.75 in logarithm form) for Singapore in 2014. The relatively large standard deviation of investment stock shows a big difference in attracting China's investment in that region. Also the large standard deviation of bilateral trade and per capita GDP indicates that the trade relations and market size are quite different as well. Besides, the cost of geographical distance has relatively small standard deviation.

\subsection{Results and discussion}

Table 2 presents results on how cultural distance and institutional distance between China and the host countries shape the patterns of Chinese outward investment to the OBOR area. We do find that the estimated coefficient for institutional distance is negative and statistically significant. Similarly, trade relationship casts a negative impact on location choice of Chinese FDI, indicating the substitution between these two activities. Besides, the interaction term of geographic distance and trade is significant at $5 \%$. We now discuss each of these main findings in more detail.

Cultural distance has a strong influence on the location choice of Chinese FDI towards the OBOR region. The negative sign of the variable indicates its impact exerted on Chinese OFDI. This result suggests that Chinese firms would prefer FDI locations where a small cultural distance existed between China and the host countries. However, it is not statistically significant in our results. This is partly due to the short period of our observation, in which culture is unlikely to change greatly. Therefore, the variation in FDI stock caused by cultural distance is insignificant. The interaction term between cultural distance and bilateral trade is significant, suggesting that the "benefit of foreignness" (i.e. differentiation of products) has played an important role in explaining the motive behind Chinese OFDI.

We find that the coefficient on the institutional distance indicates a negative relationship between institutional distance and Chinese FDI since greater institutional distance increases the costs of doing business in a foreign country, because it is associated with greater uncertainty and non-familiarity with the local environment. We can infer from the estimation results that if the institutional distance increases by one unit, it is associated with a decrease in Chinese FDI by $10.1 \%$ (model 1$)$.

Bilateral trade is negatively significant at $1 \%$, indicating that trade substitutes Chinese FDI towards the host countries. The positive sign of interaction between 
geographical distance and trade suggests that the greater geographical distance resulting in higher trade costs leads to more Chinese firms entering into the host country by direct investment instead of trade. Surprisingly, the coefficient of host country's GDP per capita is insignificant, which suggests that Chinese investment in the OBOR regions is not motivated by market-seeking. For example, BYD Auto Corporation built an electric bus factory in Hungary and it is planned to produce the bus chassis for the UK. The central location and engineering excellence are the reason for BYD's investment (BYD Europe, n.d.).

Table 2. Empirical results

\begin{tabular}{|c|c|c|c|c|c|}
\hline \multirow{2}{*}{ Variables } & \multicolumn{5}{|c|}{$\ln$ OFDI } \\
\hline & $(1)$ & $(2)$ & $(3)$ & $(4)$ & $(5)$ \\
\hline CD & 2.669 & -4.593 & -1.489 & -8.656 & -9.312 \\
\hline & $(9.318)$ & $(9.66)$ & $(9.573)$ & $(9.914)$ & $(9.879)$ \\
\hline ID & $-0.101^{* * *}$ & $-0.10^{* * *}$ & $-0.99^{* * *}$ & $-0.100^{* * *}$ & 0.339 \\
\hline & $(0.032)$ & $(0.031)$ & $(0.032)$ & $(0.031)$ & $(0.262)$ \\
\hline LnTRADE & 0.089 & $-4.142^{* *}$ & $-1.341^{*}$ & $-5.009^{* * *}$ & $-5.108^{* * *}$ \\
\hline & $(0.163)$ & $(1.645)$ & $(0.734)$ & $(1.716)$ & $(1.709)$ \\
\hline LnAGDP & 0.638 & 0.620 & 0.807 & 0.785 & 0.666 \\
\hline & $(0.627)$ & $(0.619)$ & $(0.632)$ & $(0.625)$ & $(0.626)$ \\
\hline CD*InTRADE & & & $0.722^{*}$ & $0.142^{*}$ & 0.120 \\
\hline & & & $(0.413)$ & $(0.084)$ & $(0.085)$ \\
\hline ID*InTRADE & & & & & $-0.020^{*}$ \\
\hline & & & & & $(0.012)$ \\
\hline InDIS*InTRADE & & $0.314^{* *}$ & & $0.318^{* *}$ & $0.349^{* * *}$ \\
\hline & & $(0.127)$ & & $(0.126)$ & $(0.127)$ \\
\hline & & & & & \\
\hline Country & Yes & Yes & Yes & Yes & Yes \\
\hline Year & Yes & Yes & Yes & Yes & Yes \\
\hline & & & & & \\
\hline N & 252 & 252 & 252 & 252 & 252 \\
\hline R-squared & 0.685 & 0.694 & 0.689 & 0.698 & 0.702 \\
\hline
\end{tabular}

Note: Standard errors are in parentheses; "', "' and "indicate that the coefficients are significant at the $1 \%, 5 \%$ and $10 \%$ levels, respectively. 


\section{Conclusions}

This paper is one of the first attempts to formally model Chinese OFDI towards the OBOR countries. Our motivation is to test the extent to which cultural and institutional distance affect Chinese OFDI. Based on the panel data of China's investment stock in the OBOR region from 2006 to 2014 and using fixed effect regression model, our main findings are consistent with the conventional theory explaining emerging country's FDI. Institutional distance plays a significant role in shaping Chinese investments towards the OBOR countries. This finding suggests that Chinese MNEs are targeting FDI location where it has smaller differences in institutions. Furthermore, the impact of culture interacts with bilateral trade. Given trade relationships and the preferences over differentiated goods based on cultural difference in the host country qualify Chinese firms for benefits. Finally, with greater geographical distance and increasing trade costs, Chinese MNEs tend to enter a host country by investment instead of trade.

The policy implications of our findings are that to facilitate the cooperation mechanisms for the Belt and Road initiative, we should pay more attention to institutional differences among countries. Especially for transition and developing economies as FDI recipients, the governments should focus on strengthening economic institutions in attracting FDI.

Despite the above contributions, we believe that our study has some limitations that can be addressed in future research. One limitation of this study is that due to the availability of data, we focus on the analysis on the country level. Results based on aggregate statistical data make it difficult to determine the various impacts of culture on investment for products with different intensity factor, since some products are culture-intense (i.e. shooting movies) while others are insensitive to culture changes (i.e. digital products). Thus, research at industry or even firm level may be helpful in solving this problem in the future.

Lin Zhang is lecturer of economics at the School of Business, Shanghai University of International Business and Economics (SUIBE). She obtained her Doctor of Economics degree from Shanghai University of Finance and Economics in China in 2011. She specializes in industrial development and investment in Central and Eastern European Countries (CEECs).

Zheqian Xu from Jiangsu Province in China is a postgraduate in SUIBE, majoring in industrial economics. 


\section{References}

Aleksynska, M. \& Havrylchyk, O. (2013), 'FDI from the south: The role of institutional distance and natural resources,' European Journal of Political Economy, vol. 29, no. 1, pp. 38-53. https://doi.org/10.1016/j.ejpoleco.2012.09.001

Buckley, P. J.; Clegg, L. J.; Cross, A.R.; Liu, X.; Voss, H. \& Zheng, P. (2007), 'The determinants of Chinese outward foreign direct investment,' Journal of International Business Studies, vol. 38, no. 4, pp. 499-518. https://doi.org/10.1057/palgrave.jibs.8400277

Busse, M.; Königer, J. \& Nunnenkamp, P. (2010), 'FDI Promotion through Bilateral Investment Treaties: More Than a Bit,' Review of World Economics, vol. 146, no. 1, pp. 147-177. https://doi.org/10.1007/s10290-009-0046-X

BYD Europe (n.d.), BYD Company Ltd. [Homepage] Retrieved from http://www. bydeurope.com/news/news.php?action=readnews\&page $=1 \&$ nid $=231$ [accessed 9 May 2017]

Cheung Y. \& Qian X. (2009), “Empirics of China's outward direct investment," Pacific Economic Review, vol. 14, no. 3, pp. 312-341. https://doi.org/10.1111/j.14680106.2009.00451.x

Chin, H. \& He, W. (2016), The Belt and Road Initiative: 65 Countries and Beyond, Hong Kong: Fung Business Intelligence Centre.

China Huadian Corporation (n.d.), [Homepage] Retrieved from http://eng.chd.com.cn/ webfront/webpage/web/contentList/channelId/f3e3fbb5093f4702a0603b075f6ff263/ pageNo/1 [accessed 8 May 2017]

Desbordes, R. \& Vicard, V. (2009), 'Foreign Direct Investment and Bilateral Investment Treaties: An International Political Perspective,' Journal of Comparative Economics, vol. 37, no. 3, pp. 372-386. https://doi.org/10.1016/j.jce.2009.05.001

Dikova, D.; Sahib, P. R. \& Witteloostuijn, A. V. (2010), 'Cross-border acquisition abandonment and completion: the effect of institutional differences and organizational learning in the international business service industry, 1981-2001,' Journal of International Business Studies, vol. 41, no. 2, pp. 223-245. https://doi.org/10.1057/jibs.2009.10

Filippaios, F.; Papanastassiou, M. \& Pearce, R. (2003), 'The evolution of US outward foreign direct investment in the Pacific Rim: A cross-time and country analysis,' Applied Economics, vol. 35, no. 16, pp. 1779-1787. https://doi.org/10.1080/0003684032000154220

Flores, R. G. \& Aguilera, R. V. (2007), 'Globalization and location choice: an analysis of US multinational firms in 1980 and 2000,' Journal of International Business Studies, vol. 38, no. 7, pp. 1187-1210. https://doi.org/10.1057/palgrave. jibs. 8400307 
Kang, Y. F. \& Jiang, F. M. (2012), 'FDI location choice of Chinese multinationals in East and Southeast Asia: Traditional economic factors and institutional perspective,' Journal of World Business, vol. 47, no. 1, pp. 45-53.

https://doi.org/10.1016/j.jwb.2010.10.019

Kogut, B. \& Singh, H. (1988), 'The effect of national culture on the choice of entry mode,' Journal of International Business Studies, vol. 19, no. 3, pp. 411-432. https://doi.org/10.1057/palgrave.jibs. 8490394

Kolstad, I. \& Wiig, A. (2012), 'What determines Chinese outward FDI?' Journal of World Business, vol. 47, no. 1, pp. 26-34. https://doi.org/10.1016/j.jwb.2010.10.017

Kostova, T. (1997), 'Country institutional profile: concept and measurement' in Academy of Management Proceedings, no. 1, pp. 180-184. https://doi.org/10.5465/ ambpp.1997.4981338

Lankhuizen M.; de Groot H. L. F. \& Linders, G.-J. M. (2011), 'The trade-off between foreign direct investment and exports: the role of multiple dimensions of distance,' The World Economy, vol. 34, no. 8, pp. 1395-1416. https://doi.org/10.1111/j.14679701.2011.01335.x

Li, P.; Meng, H. \& Li, Y. (2014), "Bilateral investment agreements and China's outward foreign direct investment: from the perspective of institutional distance," World Economy Study, vol. 33, no. 12, pp. 53-58.

Meyer, K. E.; Estrin, S.; Bhaumik, S. K. \& Peng, M. W. (2009), 'Institutions, resources, and entry strategies in emerging economies,' Strategic Management Journal, vol. 30, no. 1, pp. 61-80. https://doi.org/10.1002/smj.720

Ministry of Commerce of PRC (2016), 2016 Report on development of China's outward investment and economic cooperation, Ministry of Commerce of the People's Republic of China.

Neumayer, E. \& Spess, L. (2005), 'Do bilateral investment treaties increase foreign direct investment to developing countries?' World Development, vol. 3, no. 1, pp. 31-49. https://doi.org/10.1016/j.worlddev.2005.07.001

NDRC (2015), 'Vision and Actions on Jointly Building Silk Road Economic Belt and 21st-Century Maritime Silk Road,' National Development and Reform Commission, Ministry of Foreign Affairs and Ministry of Commerce of the People's Republic of China.

OECD (2015), 'China in a Changing Global Environment.' Retrieved from http://www.oecd. org/china/china-in-a-changing-global-environment_EN.pdf [accessed 8 May 2017]

Qi, J. H. \& Yang, L. (2012), 'Determinants of Chinese OFDI Location: Based on the Geographical Distance and Cultural Distance Test,' Economic Geography, vol. 32, no. 12 , pp. $40-46$.

Ramasamy, B.; Yeung M. \& Laforet, S. (2012), “China's outward foreign direct investment: location choice and firm ownership," Journal of World Business, vol. 47, no. 1, pp. 17-25. https://doi.org/10.1016/j.jwb.2010.10.016 
Randøy, T. \& Dibrell, C. C. (2002), 'How and why Norwegian MNCs commit resources abroad: beyond choice of entry mode,' Management International Review, vol. 42, no. 2, pp. 119-140.

Statistical Bulletin (2015), 2014 Statistical Bulletin of China's Outward Foreign Direct Investment, Ministry of Commerce, National Bureau of Statistics and State Administration of Foreign Exchange, Beijing: China Statistics Press.

Thomas, D. E. \& Grosse, R. (2001), 'Country-of-origin determinants of Foreign Direct Investment in an emerging market: the case of Mexico,' Journal of International Management, vol. 7, no. 1, pp. 59-79. https://doi.org/10.1016/S1075-4253(00)00040-5

Tian, H. (2015), 'The regional differences of the influence of national cultural distance on Chinese import-export trade,' Economic Geography, vol. 35, no. 2, pp. 22-29.

UNCTAD (2016), World Investment Report 2016: Investor Nationality-Policy Challenges, United Nations Conference on Trade and Development, Geneva: UN.

World Bank (2014), Sustainable Energy for All (SE4ALL) database. Retrieved from http:// data.worldbank.org/indicator/EG.ELC.ACCS.ZS ?locations=KH\&view=chart [accessed 8 May 2017]

World Values Survey (n.d.), WVS. [Homepage] Retrieved from http://www. worldvaluessurvey.org/wvs.jsp [accessed 8 May 2017]

Xinhua (2016), “Chinese enterprises enter 'Go Global' era 4.0.” Retrieved from http://english.gov.cn/news/top_news/2016/04/11/content_281475325205328.htm [accessed 8 May 2017]

Xu, D. \& Shenkar, O. (2002), 'Institutional distance and the multinational enterprises,' Academy of Management Review, vol. 7, no. 4, pp. 608-618.

Xu, H. L. \& Li, L. H. (2011), 'The effects of cultural differences on location decisions of Chinese foreign direct investment,' Statistics and Decision, vol. 27, no. 17, pp. 154-156.

Yin, H. F. \& Lu, M. H. (2011), 'Cultural distance and Foreign Direct Investment flows: the S-curve hypothesis,' South China Journal of Economics, vol. 29, no. 1, pp. 26-38.

Zhiqiye (n.d.), 'List of Chinese companies investing abroad.' Retrieved from http://www.zhiqiye.com/report/global/1.html [accessed 21 Oct 2016]

Zong, F. Y.; Lu, J. Y. \& Wu, C. Q. (2012), 'Bilateral investment treaties, institutional environment and Outward FDI location choices of firms - an empirical study of Chinese listed firms,' Economic Research Journal, vol. 57, no. 5, pp. 71-82. 